\title{
CONCEPTUAL FRAMEWORK ON THE FACTORS INFLUENCE THE EFFECTIVENESS OF CLAIMING DECEASED ASSETS BY MUSLIM INHERITORS
}

\author{
Khairatun Hisan Idris Shazali* \\ Faculty of Business and Technology, UNITAR International University, Malaysia \\ Nor Zarina Abu \\ Faculty of Business and Technology, UNITAR International University, Malaysia \\ Dr. Nasyra Ab. Jamil \\ Faculty of Business and Technology, UNITAR International University, Malaysia \\ *Corresponding Author
}

\begin{abstract}
This conceptual study is to propose the conceptual framework on the factors that influence the effectiveness of claiming deceased assets by Muslim inheritors.

It is an exploratory study, and a semi-structured interview method will be used by interviewing the subjects on the difficulties that they faced during the claiming process of the deceased assets. The conceptual framework based on two types of variables that are Independent Variables and Dependent Variable. Three hypotheses were discussed to understand the relationship between the independent and dependent variables.
\end{abstract}

Key words: effectiveness, claiming, assets, Muslims, inheritor.

Cite this Article: Khairatun Hisan Idris Shazali, Nor Zarina Abu and Nasyra Ab. Jamil, Conceptual Framework on the Factors Influence the Effectiveness of Claiming Deceased Assets by Muslim Inheritors, International Journal of Management, 11(12), 2020, pp 443-448.

http://iaeme.com/Home/issue/IJM?Volume=11\&Issue $=12$

\section{INTRODUCTION}

Islamic estate planning exists for more than 1400 years ago, during the revelation of Al-Quran to the Prophet Muhammad (s) as a guidelines to all mankind, The uniqueness of Islamic Estate Planning as compared to conventional estate planning is grounded on the existence of shari'ah as the guideline that never changes. 
However, there are lacking knowledge among the Muslims that cause misinterpretation and misconception on the importance of estate planning for the Muslims. Hence, the ignorance contributes to the increasing of the unclaimed deceased asset and frozen assets among the Muslims due to delaying the process of claiming the inheritance estate (Nordin et al., 2013). The delaying on process also contributed by to administration and management issue of insufficient number of officers in Estate Distribution section as studied by Shafie et al. (2016), explained that there was awareness among the clients on processes and procedures to follow, however, there are fewer officers to manage the inheritance cases causes of delay in distribution of the deceased assets.

According to Kamarudin et al. (2019), most of the literature previously found that Malaysian are lack of awareness on Islamic estate planning. Bouteraa (2019) adds that Islamic estate planning is seriously ignored by the Malaysian Muslims, which is the main reason for the continuous increase in the unclaimed inheritance due to various behavioral factors such as zero-knowledge and lack of awareness of the Islamic estate planning, in addition to the wrong perception of fara'id among the society, the social influence and the religiosity have a vital significance in non-practice of the Islamic estate planning as well.

According to Baharul-Ulum et al. (2017), demographic factors that influenced the unclaimed deceased assets awareness among the Kelantanese are income and status.

Bernama (2018) reported that RM66.6 billion Muslims unclaimed assets in Malaysia. The deceased hard work and energy to provide a better life for their heirs and kindred are useless when the inheritors cannot utilize it. Therefore, it is a loss of the Muslim society as a whole.

Statistic on causes of death, in Malaysia, 2018 by Department of Statistics Malaysia shows that the highest percentage of death in Malaysia are at age between 15 to 40 years due to transportation accidents $(22.5 \%)$. Next to it is due to ischemic heart disease $(17.8 \%)$, the age range is between 41 to 59 years, and $16.4 \%$ due to pneumonia with the range age is 60 years and above. From the statistic, it can be concluded that the highest range of death age is 40 years and above. If those deceased are the head or the breed winner of the family, losing them will cause a significant financial impact to the family or dependents. Leaving the dependents without assets would be a struggle to them and leaving the dependents with assets that hardly unfreeze is worst. The concern on the increase of the unclaimed assets in Malaysia has influenced for it to be explored more particularly on the factors that contribute to the issue.

\section{FARA'ID}

Fara'id is one of the tools in deceased assets distribution. It is a method to calculate the proportion percentage or amount that will be received by the recipients or inheritors. Therefore, it is important to document the input and information of the deceased, deceased asset and liabilities to be submitted to the right authority to legalize the assets before it can be distributed according to fara'id proportion.

From the Qur'anic perspective, verses on fara'id or the Islamic Law of inheritance is one of the verses expressly revealed and explained in detail with regards to the rights and entitlement of each legal heir as mentioned in the Al-Quran Chapter 4 (An-Nisa'): verses 11.12 and 176. No other religious book or divine sources containing the code of distribution is as specific and precise as in the Qur'an. The knowledge of fara'id is so important that the Prophet (the exhorted us not only to learn but also to teach it to others. He further declared that the knowledge of fara'id to be half of knowledge and the first knowledge to be uplifted; and that there will come a time when two people will quarrel about fara'id and they cannot find a person who can settle their dispute. He said in one of the hadith: 
"Learn the law of estate distribution and teach them to people; for it is one half of knowledge and it will be forgotten and the first to be withdrawn from my community.'[Shaykh Nasir al-Din al-Albani opined that this hadith is weak. Ibn Kathir also quoted this hadith but he cited al-Dhahabi who said that in the chain of narrators, there is Hafs ibn 'Umar ibn Abi 'Ataf who is weak. Nevertheless, Ibn Kathir quoted Ibn 'Uyaynah who said: Knowledge of al-Fara'id was called half of knowledge, because it affects all people.]

The knowledge will not be taken away directly from humans, but rather through the death of scholars who are experts in the field. This is in accordance with the hadith, Abdullah $b$. 'Amr b. al-'As reported Allah's Messenger (

"Verily, Allah does not take away knowledge by snatching it from the people but He takes away knowledge by taking away the scholars so that when He leaves no learned person, people turn to the ignorant as their leaders; then they are asked to deliver religious verdicts and they deliver them without knowledge, they go astray, and lead others astray.[Sahih Muslim 2673a; In-book reference: Book 47, Hadith 22; USC-MSA web (English) reference (deprecated numbering scheme) : Book 34, Hadith 6462.]

\section{DECEASED ASSETS}

The assets of the deceased can be divided into two categories. One is known as movable assets and another category is known as non-movable assets. Among the movable assets are cash, investment (eg. share), commodities (eg. gold), EPF, takaful, bitcoin, while nonmovable are land, house, and building.

\section{METHODOLOGY}

This study is an exploratory study by interviewing the subjects on the difficulties that they faced during the claiming process of the deceased assets. A semi-structured interview method will be used where the interviewer prepares a set of the same questions to be answered by all interviewees. At the same time, additional questions might be asked during interviews to clarify and/or further expand certain issues. It will begin at the stage of data collection and continues throughout the process of transcribing, reading, and re-reading, coding, analyzing, and interpreting the data.

The hypotheses for this study as follows:

\section{Hypothesis 1}

H1: There is a significant relationship between Awareness and Effectiveness of Claiming Deceased Assets.

\section{Hypothesis 2}

H2: There is a significant relationship between Types of Assets and Effectiveness of Claiming Deceased Assets.

\section{Hypothesis 3}

H3: There is a significant relationship between documentation and Effectiveness of Claiming Deceased Assets.

\section{PROPOSED CONCEPTUAL FRAMEWORK}

Figure 1 below is a conceptual framework based on two types of variables which are Independent Variables and Dependent Variable. The Independent Variables consist of the factors that influence the delay or not claiming the deceased assets namely as awareness, 
types of assets, and documentation. The Dependent Variable consists of the effectiveness of the Muslims in claiming the deceased assets. However, based on the interview, the respondents mentioned that even though some of the inheritors are aware on the importance of settling the distribution of deceased assets, and types of assets are identified and fulfilled all the documentation, other reasons that caused the delaying or freezing of the claiming process are time, cost and argument among the inheritors or heirs. Therefore, those factors are created as the mediator between the independent and dependent variables. It intervenes in the process and adds the delays of assets claiming. The proposed conceptual framework was developed by referring to the model established by Kamaruddin et al. (2019) as a basis.

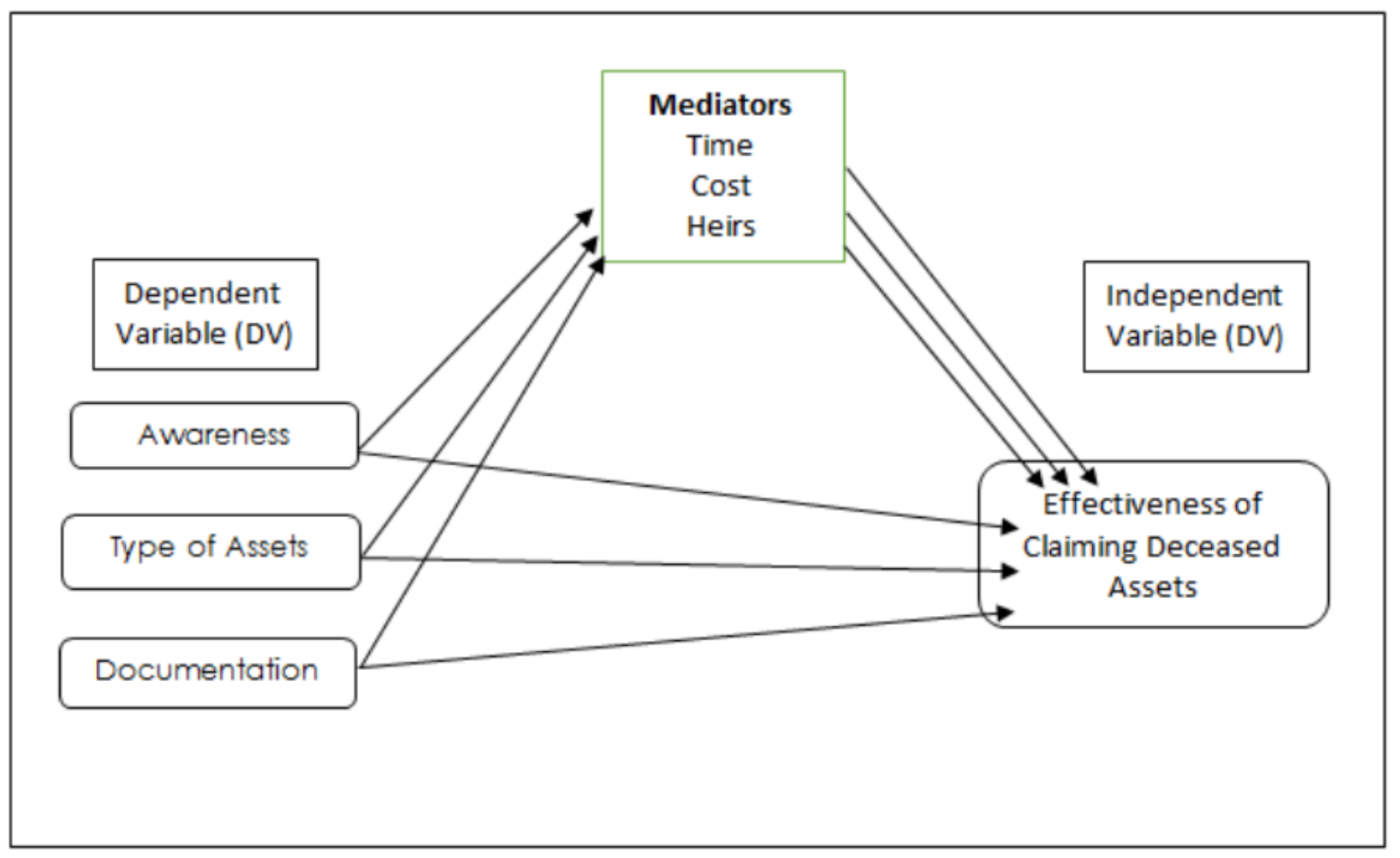

Figure 1 Proposed Conceptual Framework

\section{Relationship between Awareness and Effectiveness of Claiming Deceased Assets}

Awareness is the main factor for an individual to actively involved in any activities. Lack of awareness will be caused by ignorance and less pushing factors to drive the individual to solve the issue on estate distribution, support by Shafie et al. (2016). Furthermore, Shafie et al. (2016) added that the misinterpretation view of society that there should be no urgency to speed up the distribution of property to ovoid misinterpretation and out of respect for the deceased also restricts the process of distribution of the estate from being made immediately.

\section{Relationship between Types of Assets and Effectiveness of Claiming Deceased Assets}

Some might think that the effectiveness of managing deceased assets will be difficult when the numbers of assets are a lot, or the numbers of assets are huge. However, numbers might be one of the issues but managing all the assets will be difficult when the information is not transparent or available. Regardless the deceased assets are more or less, big or small, when the information is not available, the period of distribution of the assets will be prolonged. Thus, it will drag the time to gather and distribute the deceased assets. This also will need the administrator to spend more especially on traveling and transportation costs. It will be more 
difficult when it is hard to get consent from the heirs. According to Nordin et al. (2012), there are time and cost issues in the present Islamic inheritance distribution process.

\section{Relationship between Documentation Process and Effectiveness on Claiming Deceased Assets}

Documenting all the necessary documents related to the deceased assets is very crucial for the application of deceased assets distribution. There are forms to be completed and then submitted to the authority to process for the approval of the administrator to execute the distribution of the assets. Failed to fulfill the information will delay the claiming process, hence, it needs the appointed administrator to reconcile the information gaps. This will incur costs and time-consuming. Another reason to drag the gathering of information sometimes due to disagreement and lack of commitment among the heirs. This was support by Hassan et al. (2014), Nordin et al. (2012), and Shafie et al. (2015 \& 2016).

\section{CONCLUSION}

According to the analysis, all three factors had influenced the effectiveness of claiming the deceased assets. And the process becomes more difficult when other factors influence the three factors. A further study needs to be done to identify the root cause of the delaying the claiming or not interested to claim the deceased assets.

However, this study provides a useful insight into Islamic financial planning and Islamic estate planning areas. This study is related to several parties such as the authorities (State Religious Council, Land and Mines Department, Small Estate Distribution Department and government agencies that offering the service-related product to Islamic estate planning. This might help financial planners, estate planners, and educators to design better guidelines for their clients to improve in the usage of the tools in Islamic estate planning.

\section{REFERENCES}

[1] Baharul-Ulum, Z.K.A., Naser M., M.F.K., Zahari M., M.K.A., Ramli M., M.S.A \& Amran, M.A. (2017). Unclaimed Assets Awareness among Muslims in Kelantan: Demographic Evidences Al Qimah Al Mudhafah The Journal of Management and Science (ALQIMAH), Volume 2, Issue 1.

[2] Bernama (Friday, 01 Jun 2018) Pahang Regent says unclaimed Muslim inheritance amounts to RM66.6 billion.

[3] Bouteraa, M. (2019). Conceptual Study: Barriers of Islamic Estate Planning. IBMRD's Journal of Management \& Research Volume 8, Issue 1, Print ISSN : 2277-7830, Online ISSN: 23485922.

[4] Department of Statistic Malaysia (2018). Press Release: Statistic on Causes of Death, Malaysia, 2018, EMBARGO: Only to be published or disseminated at 1200 hours, Wednesday, 31 October 2018.

[5] Ghul, Z.H., Yahya, M.H. \& Abdullah, A., (2015). Wasiyyah (Islamic will) Adoption and the barriers in Islamic inheritance distribution among Malaysian Muslims, 2International Journal of Humanities Social Sciences and Education pp 1-11.

[6] Hassan, S.A., \& Rashid A., R., (2014). The Legal Rights and Duties of Administrators and Executors of Deceased Muslims' Property in Malaysia. https://www.researchgate.net/publication/303749182

[7] Kamarudin, N.S., Mohd H., A.J., Jamil, N.N. \& Abdul H., N. (2019). The Conceptual Framework of The Intention on Islamic Estate Planning Practice Among Muslim 
Conceptual Framework on the Factors Influence the Effectiveness of Claiming Deceased Assets by Muslim Inheritors

Entrepreneurs, Journal of Islamic, Social, Economics and Development (Jised), Vol. 4, Issues 20, pp. 69-67. Journal Website: Www.Jised.Com.

[8] Noordin, N., Shuib, A., Zainol, M. S., \& Mohamed Adil, M. A. (2012). Review and Challenges in Islamic Distribution in Malaysia. OIDA International Journal of Sustainable Development, 3(12), 27-38.

[9] Noordin, N., Shuib, A., Zainol, M. S., \& Adil, M. A. M. (2013). Delay in Islamic Inheritance Claim-An Ignorance Issue. Procedia-Social and Behavioral Sciences, 90, 504-512.

[10] Shafie, F., Wan Yusoff, W.Z, \& Al-Edrus, S.M.D (2015), Proceedings of the 25th International Business Information Management Association Conference - Innovation Vision 2020 : From Regional Development Sustainability to Global Economic Growth, IBIMA 2015.

[11] Shafie, F., Wan Yusoff, W.Z, \& Al-Edrus, S.M.D (2016). Factors of Failure and Delay in Islamic Inheritance Distribution in Malaysia. Jurnal Teknologi (Sciences \& Engineering) 